\title{
Theistic Humanism and the Critique of Monotheism as the Most Evolved Religion
}

\author{
Chiedozie Okoro \\ Department of Philosophy, Faculty of Arts, University of Lagos Akoka, Yaba, Nigeria \\ Email: chiedozieokoro@gmail.com
}

Received September 22 ${ }^{\text {nd }}, 2012$; revised October 21 ${ }^{\text {st }}, 2012$; accepted November $7^{\text {th }}, 2012$

\begin{abstract}
The main thrust of this essay is to examine how Maduabuchi Dukor's theory of theistic or spiritual or comprehensive humanism (2010: p. 77) or what I choose to call theistic pluralism, can be made the basis for deconstructing and resolving the crisis created by monistic and monotheistic orientations in the African psyche and on the African continent. The need for such demolition and resolution exercise is intensified by the fact that theistic or pluralistic humanism promotes the temperament of-live and let live (i.e. the Igbo onye biri ibeya biri) as against the monistic and monotheistic orientations which propagate a "thread bare kind of humanism" (p. 63). Consequently, my critique of monotheism is basically focused on the African condition. As of today and with the aftermath of double strands of colonization Africa is beset with the Triple Heritage problem. The razor of my critique is pointedly directed at the expression triple heritage, which not only portrays the psychological state of the African, but in actual fact determines the totality of the African condition in contemporary times. In launching my attack on the triple heritage concept, I go through the window of monotheism. Therefore, my critique of monotheism is intended for the following reasons: 1) to explore the metaphysics of monotheism, which I hereafter refer to as theistic monism, and bring to the open the consequences of such orientation in a pluralistic society; 2) to examine the metaphysics of Traditional African Religion (ATR), which in agreement with Maduabuchi Dukor, I hereafter christen theistic humanism or theistic pluralism, with a view to showing that African traditional thought system is antithetical to the monotheistic culture of the Arab and the Caucasian; 3) to query the rationale behind juxtaposing metaphysical systems that are antithetical to one another, in the name of triple heritage; and 4) to suggest way(s) of drastically ameliorating the anomaly on ground.
\end{abstract}

Keywords: Theistic Humanism/Pluralism; Monotheism; Polytheism; Triple Heritage

\section{Introduction}

The term critique entails the critical and technical analysis of issues intended to outline the positive and negative angles to such issues. It is a demolition process of critical judgment of some salient ideas about certain structure that one approves or disapproves of. In actual fact, thinking or reasoning involves the act of destructuring obsolete ideas and of drawing up new plans for rebuilding old edifices afresh. As a process of deconstruction a critique has as its main target the rehabilitation of obsolete structures for the purpose of transforming and improving the human condition. Consequently, the present discourse proceeds by way of acknowledging the advantage of monotheism in assisting a people to build the aggressive and strict orientation needed for the rapid development of their society and the dogged defence of their worldview. However, given that monotheism is absolutist, totalitarian and impositional, given also that the monotheistic temperament is the basis for intolerance and the so much acrimony in the world today, one wonders if a religious orientation that fans the embers of war and encourages the dehumanization of humanity is worthy of being ranked as the most advanced form of religion.

At this juncture I make a departure from monotheism and embark upon the refutation of the assertions of Ludwig Feuerbach and George Wilhelm Hegel that Christian monotheism is the most developed form of religion. My approach shall be one of a two-way attack, in which I shall make a hermeneutic assessment of monotheism and a deconstruction of the term polytheism. On the whole, the process of hermeneutic deconstruction shall reveal that it is a misnomer to address African Traditional Religion (ATR) as being polytheistic. It shall also be shown that the term polytheism does not necessarily mean the worship of many Gods, but the view that God is one ultimate, indivisible reality that can be understood and approached from as many dimensions as possible. Hence, instead of polytheism, I speak of theistic pluralism, of theistic humanism. In the same vein, monotheism does not necessarily mean the worship of one God, but the dogged insistence that there is only one superior God and only one superior way of serving this superior God, meaning that monotheism is in actual fact theistic monism.

By the critique of monotheism, I do not intend to suggest that its very idea and practice should be discarded or abolished, but to expose the danger monotheism poses to the world at large, and to argue that the monotheistic orientation is inadequate for organizing the affairs of a pluralistic society. The danger in monotheism lies in its vicious, totalitarian and absolutist nature to either psychologically intimidate or forcibly coerce nonadherents to accept its tenets as uppermost and God ordained, thereby promoting the antagonistic attitude of winner takes all and loser looses all. Such antagonistic and discriminatory attitude is definitely inappropriate for organizing the affairs of a 
pluralistic society.

The phrase pluralistic society refers to the new state (i.e. black African countries) in Africa created by the erstwhile colonialists. Colonialism through the process of balkanization merged together people of different ethnicities. Coupled with this is the presence of three different religious strands. So the pluralistic society I speak of is one that is multi-ethnic, multicultural and multi-religious. A problem of which metaphysical orientation best suits the organization of such multidimensional society then ensues. Is it the monistic order of theistic monism or the pluralistic order of theistic humanism? The foregoing question is addressed by the methodology of critique I have adopted which is known as hermeneutic deconstruction, which forms the hob of African symbiotic metaphysics, Heidegger's hermeneutic phenomenology and postmodernism.

Hermeneutic deconstruction is a process of technical assessment of issues which yields interpretations meant to reveal or bring to light facts which hitherto appear hidden. Beyond revealing that which appears concealed, the fundamental thing about hermeneutic appraisal of issues is that it should suggest ways of resolving problems amicably. Hence, central to hermeneutic interpretation is the principle of duality. In duality contraries and opposites are not seen as exclusive, discriminatory, compartmentalized and antagonistic, but rather inclusive, mutual, symbiotic, complementary, interconnected and equiprimordial. Within this principle of duality, technical interpretation which yields revelations further rotates on a cyclical triad.

The cyclical triad I speak about consists of the concept of the circle and the tripod. The concept of the circle shows the interconnectivity among things. To illustrate, contrary to Hegel's and Marx's principles of dialectics which portray progress and development to be linear, hence, unidirectional, such that permanence (rest) and change (motion) are seen to be antithetical or antagonistic; the concept of the circle in hermeneutics shows that permanence and change are complementary, making progress and development to be cyclical. Thus in Heidegger's hermeneutic phenomenology we see that non-being is not in opposition to being, neither is being a position prior to nonbeing, such that the antagonism between the two results into a synthesis. Rather, being and non-being are simply equi-primordial. Equi-primordiality in this instance, means that being and non-being mutually co-exist. Like male (positive) and female (negative) factors are complementary, being and nonbeing as opposites and contraries, symbiotically inter-relate. Needless to say, the complementarity of being and non-being makes the entire cosmos to be in eternal process, eternal state of becoming, propped up on the duality of permanence (rest) and change (motion), thereby making the universe order to be cyclic. The cyclical order of the universe in turn rotates on the triad of the past, the present and the future. In the African symbiotic metaphysics, we see that the past, the present and the future are one integrated whole captured in the age grade system, mortuary and birth rites, and in the institution of the ancestors. As the aged (representing the past) depart through mortuary rites into the ancestral world, ancestors are assumed to transmute into the spirit world (of the future), only to be reborn as children (representing the present), who then go through the age grade process and expectedly become aged again. The circle continues ad infinitum. This order of concentric circles otherwise called the cyclical triad is aptly represented with an equilateral triangle which is superimposed in a circle, showing that the circle and the tripod are central to hermeneutics either as a logic of history or as a logic of discourse.

Elsewhere in "On the Problem of Hermeneutics" (i.e. a subtitle in the chapter one of my Ph.D thesis) and in a paper entitled: "The Logic and Epistemology of Life-Force in African Philosophy”, I made bare the procedures of hermeneutic discourse in Heidegger's hermeneutic phenomenology and in Afa divination system, which invariably constitutes the heart of African epistemology and logic. In both works I showed that central to the hermeneutic delineation of issues and events (be it in Heidegger's hermeneutic phenomenology or Afa divination) are the concepts of the circle and the tripod.

James Watson (1971), for instance, explains that Heidegger's hermeneutic phenomenology is meant to make explicit the meaning of human existence such that the concealed will be unconcealed, the veiled will be unveiled, all with a view to demystifying the ancient belief about the hiddenness of things. Consequently, Heidegger's analysis of the human condition (daseinanalytic) proceeds cyclically (i.e. in a tripological/trilogic pattern). First human concrete existence is undertaken in a careful analysis of the Umwelt, Mitwelt and Eigenwelt which correspond to the "being", "phenomenon" and "logos" (i.e. the merger of ontology and phenomenology which makes philosophy a universal phenomenological ontology). It is here that we enter into Heidegger's triangular cum tri-circle-logic, otherwise rendered; Logos as Discourse which is opposed to Logos as Logic. The former depicts logos as understanding, intelligibility, that which reveals or brings a thing to light; the latter portrays logos as ratio, logical analysis, sheer ratiocination or deliberation. Thus, Logos as Discourse designates what Heidegger regards as "Hermeneutic Situation" (1962: p. 275), which variously refers to the circular structure or circularity of both daseinanalytic and hermeneutic phenomenology. By implication, hermeneutic phenomenological discourse proceeds by way of analysis, synthesis and revelation.

The hermeneutic procedure of the Afa divination system proceeds on a tripological/tri-logic synergy of analysis, synthesis and signification. Signification here defines the result of the divination process that expectedly should reveal or unveil a particular message (i.e. prescription) which then would be applied to a given situation, making revelation and application to be by-processes of signification. What we notice at this level is that the rule of deduction (depicting holism) and the rule of induction (depicting particularism and probabilism) now role into one to produce the binary system that progresses by way of interfusion or integration. In essence, holism and probabilism are interconnected in Afa divination. It is this interconnectivity that brings about interpretation in the form of revelation. Needless to say, the revelation process is a continuous one that juxtaposes opposing views that are in turn resolved at a higher level. The assumption is that the universe of forces is one of a continuum and in such a universe; things constantly undergo alteration, hence, solutions like problems are in themselves transient. But once a problem has been deciphered and solution given, propitiation and appeasement should follow immediately for the purpose atonement. Atonement in itself is a process of reconciling the personality of the individual (who either has a problem or has erred) with the cosmic forces around such a person or with other members of the society on whose freedom the individual infringed. In this essay, I regard atonement as an intellectual process of deconstruction and reconstruction meant to address the African condition as it relates to the triple heri- 
tage problem.

Having defined my methodological approach, my next line of question is: With reference to the African condition, how does my analysis so far relate to the problems of monotheism and triple heritage? I address the foregoing question under the following subheadings: Of Theism in General, Delineation of Religious Anthropomorphisms, Religious Anthropomorphisms and the African Condition, Atonement of the African Condition, and Conclusion.

\section{Of Theism in General}

Theism derives from the Greek theos meaning God. It has been defined as "the view that all limited or finite things are dependent in some way on one supreme or ultimate reality of which one may also speak in personal terms" (Lewis, Encyc. Brit. 2010). Elsewhere, theism is defined in a broad sense to mean the belief in any god or gods, but in strict philosophical and theological sense, it refers to monotheism which is the belief in one ultimate universal God (Microsoft Encarta, 2008). Hence, theism is understood as: "Belief in one God who is personal and worthy of worship, who transcends the world but takes an active interest in it, and who reveals his purpose for human beings through certain individuals, miraculous events, or sacred writings. A theistic God is personal if he can be understood by analogies drawn from human experience and if human beings can enter into a personal relation with him and petition him in prayer. Such a God is considered worthy of worship because he is believed to be morally perfect and infinitely powerful” (Ibid.). In line with the foregoing, David L. Edwards defines theism as: "Belief at least in one God as the creator of the universe, and the savior and ruler of human life, and as transcendent because he is eternal and infinite (i.e. unlimited by space and time) as well as immanent (i.e. present and active in space and time)" (1988: p. 855).

From the above, we gather the impression that theism is about a suzerainty covenant between two unequal entities: one being supernatural, yet having the dynamism to manifest its presence in the physical; the other being natural but also possesses the ability to comprehend and conceptualize about the supernatural. The need thus arises to ask the question: What is the nature of God such that as a transcendent reality unlimited by space and time, it can immanently show its presence in space and in time?

Back in the days of catechism one was taught that God is spirit who has no beginning and no end. Later on, ones reading of the Bible revealed that of the three men (Moses, Elijah and John the writer of the book of Revelation) who tried to comprehend God in the most pure essence, two of them (John and Elijah), had encounter with light and sound. Again, ones modest knowledge of Islam reveals that Mohammed, the progenitor of Islam, in his meditations in the mountains, attained a level of spiritual consciousness where upon he discovered that man as the "I" (i.e. pure consciousness) is a microcosm of cosmic consciousness. Hence, in Islam, there is the concept of Anaaniya. The Arabic Anaa means I, while Niya means ness, Anaaniya therefore means Iness. In Islamic Sufism Anaaniya is that point of spiritual consciousness, beyond the empirical and the mental (or ideological), whereby the individual comes to realize self as a sum or spark of the total forces of the universe. It is that point where man realizes self as pure ego, and as pure ego, man is a merger of earthly and heavenly forces, it is the point where man fuses with the soul stuff of the universe and attains the realization that he is the beginning (author) and end (finisher) of all things. Anaaniya is comparable to the Buddhist Nirvana or Edmund Husserl's Transcendental Ego. In the Quran, the Anaaniya concept is reflected thus: Innani Ana'llau lailaha illa Ana, meaning "I am the Lord, there is nothing except me" (Quran 20, vs: 14). As one developed further, one began to gather a versatile view of God. For instance, my forage into Memphite theology/philosophy shows that Ptah also referred to as Logos is the uncreated primordial principle of creation comparable to the Chinese Tao, the Buddhist Universal Soul and Ein Sof (i.e. God as infinity) of Jewish Kabbala (Matt, 1997: p. 23). Then, I began to retrace my steps to ATR from where I gathered that God is pure spirit, force or vital-force, boundless, limitless and without beginning and no end. In the words of D. E. Idoniboye, for the African: "Spirit is the animating, sustaining creative life-force of the universe. Spirit is real... Its reality is primordial and it is if not superior at least as primitive as that of matter. In its pure state it is unembodied” (1973: p. 83). As unembodied spirit is immortal and transcendent, yet it possesses the dynamism to get embodied in matter only to disentangle itself when it wills. Needless to say, the ability of spirit to exist independently, get entangled with matter and later disengage, not only makes spirit transcendent and immanent, it actually makes spirit a creative force. It then began to dawn on me that force (i.e. light) and consciousness are not only connected, they are one intricate whole. My curiosity grew stronger.

To clear the air of doubt around me, assuage my curiosity and free myself of religious influences, I journeyed into science all with a view to encountering an alternative view of the ultimate reality (i.e. the ultimate source as the ens realissimum) totally different from that proffered by religion and spirituality. My discovery is amazing. In science, the doctrine of spirit is demystified. What spirituality and religion call spirit is the same as science's energy or the light-wave principle. Thus, in place of spirituality, a new theory of electromagnetism emerges. Just as spirit is immortal, has no beginning, no end, and is uncreated; energy as material essence is uncreated, indivisible, indestructible, hence like spirit is eternal, without beginning or end. Energy is in fact a law onto itself. Energy is uncreated, but it can be tapped, transferred from one body to another and also transformable from one state to another. Hence, what used to be considered the magical and miraculous dynamisms of spirit becomes the law of thermo-dynamism in science. Energy comprises dense matter and subtle matter. Dense matter portrays energy in its solid, liquid and visible gaseous state, while subtle matter portrays energy in its incorporeal and invisible state. At this level, matter as energy has no weight, no density, no mass and no smell. In this state, energy has the capacity to begin from "point zero and expand to infinity" (Weber, 1986). At this level of subtle matter, we are back to pure energy as lightwaves, which is that omega point (i.e. energy as pure consciousness) from which everything began. It is in this sense that David Bohm speaks of the "hollowmovement theory" and goes ahead to state that-creativity is nature's signature (Bohm, 1986: p. 91). To this Bohmian assertion, Stephen Hawking reiterates thus: "The point is that the new raw material doesn't really have to come from anywhere ... The universe can start off with zero energy and steal create matter" (Weber, 51).

But if you still doubt that spirituality's spirit and science's energy are one and same stuff, all you need do is to pause a 
while, and in this state of silence, take a deeper look at the characterizations of spirit in spirituality and energy in science. Spirituality posits that God as spirit is immortal, hence, is not subject to change, distance and time. Little wonder St. Augustine authoritatively proclaimed God's infiniteness thus: No time is co-eternal with thee. However, Einstein's relativity theory shows that energy as light-wave is not only co-eternal with God (spirit), it is in fact the same as God. Light travels at 182, 282 (over 310, 000 miles) kilometers per second. At this speed, there is no change, no distance, no time. We are thus back to Parmenides' Being. Einstein buttressed his new discovery with the Dual Paradox Theory. According to this theory, if we manufacture two vessels, we make one travel at the speed of light and the other at a speed less than that of light, and we put two boys (both ten years of age), one in each vessel, and make the vessels to travel ten light years and back. It will surprise us that the boy in the vessel that travels at the speed of light would remain exactly ten years old, while the boy in the vessel that travels less than the speed of light might have grown old and frail or even dead (depending on the speed his vessel travelled relative to the speed of light).

Baffling as it appears, the truth remains that both spirituality and science open us up to the realization that spirit and energy are one and the same. After all, the scientist and the mystic are both investigating the same reality but in different names. This point is reiterated by J. I. Unah as follows:

The scientific law of Conservation of Energy was formulated using the categories of matter alone (i.e. objects of empirical intuition). But the doctrine of the immortality of the Soul was formulated using the categories of the mind alone (i.e. mental constructions out of empirically unaccountable manifestations) (1997: p. 57).

The fact is that going by the doctrines of electromagnetism and spirituality energy or spirit is the self-animating, sustaining principle of the universe.

At this juncture I like to emphasize that my intention at delineating the nature of spirit is meant to demonstrate that God in its purest essence is not in any way close to the conceptions and image-nations of humans in the various world religions. In its purest essence therefore, God is simply spirit, light or consciousness, devoid of any creed or faith. However, by the forgoing submission I do not in any way imply that the God riddle has finally been cracked. It in fact remains an ongoing debate, and men will never cease, at the level of religion, to keep conceptualizing God in the images they deem fit and in accordance with the circumstances encountered. Therefore, the quest to understand the nature of the ens realissimum who as a necessary being is the ens causa sui, continues unabated. But the elusiveness of such a quest stares us in the face. This is demonstrated by the fact that the religious mind is easily intimidated and cowered by the awesomeness of the unknown and before long beholds an almighty image to whom propitiation must be made thereby, leaving the mystic and the scientist as the only ones entangled in the search for the ultimate source. But whereas empathy is the mystic's procedure of inquiry, the scientist's methodology is epistemological dissection. The mystic wants to become one with the cosmic force, so that the micro (the mystic) and the macro (cosmic force) can become interfused, the scientist observes energy (i.e. cosmic force) from a distance, his interest is to disembowel it and bring forth its hid- deness to the open. As Renee Weber explains:

In splitting the atom, the physicist releases vast amounts of energy that was needed to hold the core of the atom together, its holding power. The operation requires the physicist's intelligence, effort, time, and commitment, but not his very self, which can remain fundamentally unchanged. Of the mystic, more is required. He is engaged in deconstruction and reconstructing not some neutral external reality, but himself (1986: pp. 10-11).

In the quest for the ultimate source, the mystic takes as his laboratory his own body and his aim is to find the God (spirit) essence that lies within. The physicist seeks for the spirit essence in the atom. But both body and atom are of course material. Consequently, in the search for the God essence locked up in matter, the mystic says he encounters ether. When tasked to explode into the core of ether, the mystic says he encounters nothing. Again, in the Something Called Nothing, Physical Vacuum: What is it? Podolny (1986) explains that the quest by scientists to dig into the issue of ether ended in futility, meaning that the scientists' quest ended in a nothing. If either by way of spirituality or science, nothing becomes the end result of the quest for the primordial beginning, it means that we are in for an endless search. The search is endless because man is a diehard fanatic who will never give up on the attempt to unravel the ultimate beginning.

The bottom line of the above analysis is that man is primarily a metaphysical being who possesses the capacity and ability to transcend the limit of experience and project into the unknown all with a view to explaining that which appears mysterious. Obviously, like Hermes Trismegistus of ancient Egypt, Pythagoras, Plato, Spinoza and virtually all Eastern sages say; "the quest for outer being is bound up with the quest for inner being” (Weber, 7). Still on this matter, Miguel De Unamuno explains that "man is preoccupied with the question of God because he is preoccupied with himself, with his own existence, the meaning of his life, and especially what will happen to him hereafter" (1954: p. 114). J. I. Omoregbe on his part reiterates thus: "it is the problem of man that leads to the problem of God" (1983: p. 1). It then becomes the case (as asserted by Protagoras of Abdera) that man is the measure of all things. Man is the one speculating and conceptualizing about God. God remains hidden and can only be made manifest through the minds of humans. If this be the case, every pronouncement said to be made by God is a pronouncement made by man. In like manner, all conceptions of God are attempts by humans to adorn the hidden in the image of man. Invariably man, according to Feuerbach, is the creator of God.

\section{Delineation of Religious Anthropomorphisms}

Anthropomorphism is a way of personifying the unknown or the apparently hidden in human form. It is a way of attributing human characteristics (i.e. human forms, features and behavior) to a perceived non-human entity. Recall that spirit in its pure form is unembodied, a quality that endows it with omnipresence, just like light waves are everywhere present. Anthropomorphically, spirit is adorned in human frame; spirit acquires a human identity, a human image, thereby announcing the birth of God. In Hegel's dialectics, spirit as position stands in majesty against matter and is antithetically opposed by matter. Since spirit needs matter to manifest its majesty, it gets entan- 
gled with matter so that matter can be endowed with motion, and having accomplished substantial change in the material realm, spirit willingly disentangles from matter and reconciles itself to itself. In religion the exact opposite happens. Humans, ideologically images spirit so that spirit is forever entrapped in a designed human frame. Thus, as an anthropomorphic deity, spirit can no longer get disentangled; rather, it gets re-cloned in diverse notions. This has been the story of religious anthropomorphism in history.

But how is it possible that man is able to domesticate the unknown (i.e. spirit) in human form? The answer to the foregoing question is found in human nature. Man is both a metaphysical and an anthropological being. Anthropologically, man is immanent, sentient and transient. Metaphysically, man is a transcendent being who has the ability and capacity to transcend the bounds of experience. Therefore, metaphysically, man is able to contemplate and conceptualize about the unknown (spirit) in a pure mental form. Anthropologically, he is able to image the mental in human form. This dualistic nature of man is well articulated by Immanuel Kant in The Critique of Pure Reason (1970). Kant identified four faculties of the mind which are; reason, understanding or the apperception, imagination and sensibility. To sensibility belong the attributes of space (i.e. outer sense by which we become aware of the external world which is called sensation) and time (i.e. inner sense by which the intuited as sensation are arranged in sequence or series which we call perception). In sensibility therefore, we encounter the world in empirical form which is technically referred to as a posteriori knowledge. To the understanding belong the twelve categories through whose function of schematism we form both rational and empirical concepts about the world which technically is referred to as a priori knowledge. The imagination is the mediator between sensibility and understanding, making it to be the unifier of concepts and the intuited. As the unifier of concepts and the intuited, the imagination is both productive and reproductive, a function (quality) that makes it the faculty of trance (i.e. image formation). Reason is the faculty of transcendent ideas whose essential function is to legislate notions (ideas or ideals or forms) which are imposed on the world to direct human activities.

Now, whereas sensibility, imagination and the understanding are faculties meant to apprehend and analyze the phenomenal (physical) world, reason is the faculty of metaphysics. Present in man therefore, are both anthropological and ontological qualities (i.e. the faculties of the mind). Again, whereas the anthropological qualities of man form the basis for inductive inference (i.e. Kant's transcendental aesthetic) such that by way of abstraction (an inductive procedure), man infers from particular instances in the cosmos, a primordial beginning called the Uncaused Cause or the Unmoved Mover (i.e. Aquinas' cosmological argument for God's existence); the ontological qualities of man form the basis for deductive inference (i.e. Kant's transcendental analytic and dialectic) by which process man invokes (idealizes) a universal essence as the primordial base of all things (i.e. Anselm's ontological argument for God's existence). Little wonder in the fourth antinomy, Kant proceeded to show that the proof for the existence of a supreme being by theology is a pure speculation of reason.

The analysis done above shows that man is capable of conceiving God either as a concept or an image. Conceiving God as a concept is a pure philosophical (metaphysical) project meant to secularize the God talk for the purpose of directing human earthly affairs. The aim here is to attain earthly bliss. God conceived as an image of worship is a pure religious affair and the purpose is to create a supernatural ideal for directing human earthly activities. The aim here is to attain heavenly bliss. But whether conceived as a concept or an image of worship, God remains essentially a notion. Nonetheless, my interest is centered on the religious notion of God and it is at this juncture that I would like to discuss the issue of the worship of idol which is commonly associated with ATR.

Distinction is often made between monotheism and polytheism. Monotheism is defined as belief in one supreme and universal God, while polytheism is derogatively defined as the worship of many Gods. Because those grouped as polytheist belief that organic matter is endowed with force which man can religiously interact with, words like animism and totemism are used to qualify polytheism, in the same way as polytheist are denigrated as heathens. Microsoft Encarta (2008) defines heathen as "an offensive term that deliberately insults somebody who does not acknowledge the God of the Bible, Torah and Quran”. It is in the foregoing sense that Hegel and Feuerbach regard Christianity, Lutheran Protestantism in particular, as the most evolved form of religion. By implication, it is assumed that monotheism is a more evolved religion than polytheism. On the surface, the foregoing assertion appears to true especially, if we refer to the evolution of monotheism in ancient Egypt some 3500 years ago by Pharaoh Amenophis IV (1350 BC) of the Eighteenth Dynasty, son of Amenophis III, grandson of Thutmose III, who forcefully harmonized the whole of the Egyptian pantheon of Gods into one universal entity called Aten. Unlike other Egyptian Gods Aten was not represented in any physical image. Pharaoh Amenophis IV then changed his name to Akhenaten, meaning "son of the universal God" (i.e. Aten) and also built the city of the universal God known as Akhitaten. But like Ninian Smart warns, since in polytheism there is a bold acknowledgement of a supreme universal God who is above the smaller Gods and to whom the smaller Gods account, it is erroneous to assume that monotheism is a higher form of religion than polytheism. This assertion of Ninian Smart opens up a new opportunity for me to take a closer look at the terms monotheism and polytheism.

Recall I stated that God is spirit, that spirit in its pure essence is unembodied, and is therefore comparable to energy or consciousness. Recall I also stated that the human mind by is constitution is capable of imaging or representing the bodiless essence called God in human form, which is technically referred to as anthropomorphism. Now the imaging of God in human form can be done in two basic ways which include: mental image and physical image. At the level of mental image, physical representation of God is strictly prohibited. Thus, the hallmark of monotheism is that it represents God purely as a mental image. This mental image persists in the minds of the adherents of monotheistic religions who claim to have personal encounter with their Gods (I hereby refer to the different monotheistic conceptions of God in Judaism, Christianity and Islam). At the level of physical Image, God, the supreme universal force becomes “incertus and remotus" (Idowu, 1982: p. 142), God becomes incomprehensible in any image possible. But since God is essentially a force that is everywhere present, physical representations of it are replicated in the forms of divinities and deities. Thus, the hallmark of what has been christened polytheism is that God is not worshiped in any form (since God as force has no image), rather, divinities and deities act as intermediar- 
ies. It is along this line of thought that Maduabuchi Dukor describes ATR as African Polymonotheism (2010: p. 190), which through the processes of pantheism and panpsychism (pp. 181190) makes the practice of religion humanistic, empirical, existential and pragmatic (pp. 186,190).

It should however be noted that entities known as intermediaries are not exclusive to polytheism. Intermediaries also form the basic feature of monotheistic religions. For instance, Moses is the key figure in Judaism, in Christianity it is Jesus Christ and in Islam, Mohammed is the principal figure. Consequently, the main difference between monotheism and polytheism is not in image worship, but in the manner of approach to God. So long monotheism and polytheism are anthropomorphic in nature, it means that both are guilty of image worship, both are neck deep into idol worship. The real difference between monotheism and polytheism is that whereas the former insists that there is only one way to God, the latter states that there are innumerable ways to God. In fact, in polytheism, I as an individual, am a way to God. Same goes for every individual. The basic difference here is that whereas monotheism is monistic, reductionist and impositional, polytheism is pluralistic and therefore, humanistic.

Since like monotheism polytheism asserts the reality of one universal God, but since unlike monotheism polytheism offers us myriad ways to that ultimate realty which religion calls God, it is gravely erroneous and grossly inadequate to describe ATR as a polytheistic religion. In the light of the foregoing, Bolaji Idowu describes ATR as "Diffused Monotheism” (p. 204). I. E. Metu on his part describes ATR simply as "African Theism" (1988: p. 71; cited by Iroegbu, 1995: p. 361). Maduabuchi Dukor variously refers to it as "Theistic Humanism", Spiritual Humanism", Comprehensive Humanism" or simply as "Polymonotheism". I on the other hand think that the more appropriate description for ATR is "Theistic Pluralism". The main point here is that a religious (theistic) orientation is said to be pluralistic if it offers many ways by which one can reach or relate with spirit. In like manner, a religious (theistic) orientation is said to be monistic, reductionist and impositional if it grants only one way to reach or relate with spirit. To use Naiwu Osahon's analogy in The End of Knowledge (2002), God as spirit is comparable to the internet system which requires engines like Google, Yahoo, MSN, Hotmail, etc, to penetrate. These internet engines play similar role as the divinities in ATR, Jesus Christ in Christianity, Moses in Judaism and Mohammed in Islam. We can already see from the foregoing that whereas ATR affords us the opportunity to so many engines to penetrate into the supernatural, the monotheistic religions offer one opportunity each and still go ahead to insist that of the limited ways, only one among them is superior.

It is at this point that I depart from the conventional definitions of monotheism and polytheism. Going by the analysis made above, it is clear that monotheism is not the belief in one universal God, rather, it is the insistence that there is only one superior way to God and that whoever does not adhere to that way is doomed. In like manner, polytheism is not the belief in many Gods, rather, it is the view that there is one universal God, but that there are manner ways to reach that God. Based on this, I reject the term polytheism and in its place, I substitute the term theistic pluralism or theistic humanism. The difference here is that monotheism is guilty of caging God in the form of mental image which it considers to be eternal. Realizing this guilt of monotheism, the Indian sage Sankara declares as fol- lows:

O Lord, pardon my three sins.

I have in contemplation clothed in form Thee Who art formless:

I have in praise described Thee Who art ineffable

And in visiting temples I have ignored Thine omnipres-

ence (1945: p. 19; cited by Idowu, 1982: p. 38)

By refusing to name the ineffable source, but instead choose to make the formless become immanent in the personalities of countless divinities, theistic pluralism heeds to the admonitions of Daniel Matt who states thus: "When you contemplate the Creator, realize that his encampment extends beyond, infinitely beyond, and so on, in front of you and behind you, east and west, north and south, above and below, infinitely everywhere" (1997: p. 25). Since religion is inseparable from culture and since every people of the world developed one cultural orientation or another, the following questions readily come to mind: Would it not amount to serious conflict if religious orientations of antithetical nature are allowed to co-exist in a society? And would the conflict not be made worse if two monotheistic religions that are antagonistic to each other are allowed to co-exist with a third religious orientation which basically is pluralistic?

\section{Religious Anthropomorphisms and the African Condition}

The African condition I speak about in this instance refers to the juxtaposition of three strands of religion whose metaphysical orientations are antithetical one to the other. Incidentally, the juxtaposition of these three strange bedfellows has been dubbed triple heritage. One is then urged to take a second look at the word heritage. As denoted, the word heritage simply means legacy, status, condition or character bequeathed to or inherited from ones ancestors, family or social class. Except connotatively, the word heritage has clandestinely been adjusted to include imposed culture, to regard the culture of the invader as a heritage is to negate the saying that culture can be borrowed, adapted or readapted. Worst still, using the singular heritage instead of the plural heritages to qualify three different strands of culture, unwittingly, but inevitably propagates the spirit of absolutism which stands in contradiction to the traditional African temperament of pluralism.

Chinweizu makes it abundantly clear that the rise of monotheism tantamount to an assault on the African gender diarchy. With the ushering in of monotheism by Pharaoh Akhenaten:

The ancient spirit of tolerance and the syncretic rivalry which were traditional between the cult of Kemet's gods were abrogated and in keeping faith with the logic of monotheism, and with an iconoclastic passion alien to Kemetic temperament, Akhenaten strove to extirpate the Kemetic galaxy of gods, so that only his sole god, Aten, might shine in the sky, day and night (2005: p. 18).

Thus with the invention of monotheism by Akhenaten, the ancient spirit of syncretism and the temperament of pluralism in Egypt were destroyed. To paraphrase Allan Gardiner; the new faith of Atenism could not spread without the suppression of the countless gods and goddesses hitherto worship- "the very word for gods was a taboo” (1964: p. 228, cited by Chinweizu, 139). Akhenaten's Atenism was matrilineal in character, but it 
gave rise to three other brands of patriarchal monotheism which are Judaism, Christianity and Islam. These latter brands of monotheism bear similarities and differences with Atenism. On matters of similarities, like Akhenatenian monotheism, patriarchal monotheism is monistic, absolutists and impositional. Second, like Akhenatenian monotheism, patriarchal monotheism was founded to promote societal cohesion, political stability and economic prosperity. However, in the evolution of patriarchal monotheism from Atenism, "three important developments are discernible: a more categorical assertion of the monist attribute of the deity, massculinization of the sole deity and the rise of cultural monolatry" (Ibid. 141). We note here that Akhenaten's monotheistic God (Aten): "like other selfcreated deities of Pharaonic Egypt, was androgynous. It was addressed as 'the mother and father' of all things created" (Ibid.). Contrary to this, patriarchal monotheism declares its God to be solely male and without any female attribute which makes patriarchal monotheism to be more absolutist and totalitarian. And whereas in the Akhenatenian matriarchal monotheism, "the female and male" are combined in order to create balance in the society and by so doing, tame excessive aggression, in patriarchal monotheism, the complete absence of the female factor would leave the world at the mercy of an overzealous God who has no form of restraint. Chinweizu is more explicit on this matter.

Aten was addressed as "Thou sole god, like whom there is no other”. In Judaism and Christianity, the attribution of uniqueness is rendered as the henotheist injunction by Yahweh/Jehovah to his worshippers: Thou shalt have no other god before me". With Mohammedanism, this prima donna demand for precedence becomes the categorical declaration: “There is no god but Allah", an absolute denial of existence to all other gods. In these claims, injunctions and declarations are rooted the intolerance displayed by these religions; they sanction their adherents' zeal in eradicating the rival cults of other gods, so as to deny them recognition, precedence or existence (Ibid.).

The rise of monotheism in history meant the evolution of metaphysical monism which happens to be the ground for absolutism, reductionism, impositionism and intolerance. The monistic and reductionist attitude of metaphysical monism lays in the fact that it: "Reduces all reality to some common substance, or that it focuses attention on an ultimate divine Being. Of a variety of things that are-P, Q, R, S, T, U, ad-infinitum-a metaphysician says he sees or experiences $\mathrm{P}$ or that the thought of P occupies his mind" (Unah, 1995: p. 65). By encroaching upon the domain of another metaphysical monism sows the seed of discord, fundamentalism and violence. Hence:

When a metaphysician takes a basic position and relegates whatever does not fall within his conceptual scheme to a second order reality or a total unreality, he is thinking a nihiliating thought. When a metaphysician repudiates what does not "fit in", he nihilates it as not. In other words, metaphysical thought cancels out as nothing what does not fall within its perspective as Being (pp. 66-67).

Now, let us suppose that there are other metaphysicians holding repudiating views, the tendency is that the world is made a battle field for the supremacy of views, which soon lapses into a ding dong affair of winner takes all and loser loses all. It is in this sense that a metaphysician sees his view as the only real reality and repudiates other views either as utter nonsense or absolute nothing. This attitude of nihilism is well pronounced in patriarchal monotheism as evident in the following proclamations: "I am that I am; thou shalt have no other god beside me” (Judaism). "Christ is the way, the truth and the light, no one cometh to the father but through him" (Christianity). "Islam is the supreme 'will' of Allah and Mohammed the seal of prophets” (Islam). Such pronouncements are not just antithetical to metaphysical pluralism of the African, they fuel the ember of "fundamental blasphemy" (p. 53). Fundamental blasphemy is that interminable way of speaking without letting others express their views. It is that manner of arrogating to self the air of superiority, thereby looking down on others as the camp of opposition to be converted (either through persuasion or coercion) by every means possible. Hence, monotheism, like metaphysical monism, by attempting to subsume all existing religious systems under one universal orientation extols the attitude of fixism and the nihilistic and vengeful temperament which threatens human freedom - the freedom to "see and say" (p. 45).

By accident of Arabic and European colonization of Africa, post independence Africa harbors two main strands of patriarchal monotheism which are Islam and Christianity. These two brands of monotheism are not only hostile to each other, metaphysically; they stand in antagonistic opposition to the African thought system. Both Christianity and Islam begin from the point of negating each other. Christianity holds that Christ is the only begotten son of God; in Islam such assertion amounts to speaking "monstrous falsehood". Orthodox Christianity holds in the Trinitarian concept of one God; for Islam Allah is one and indivisible. By the doctrine of Christianity, Muslims and non-Christians in general cannot make heaven. By the Islamic doctrine, Christians and non-Muslims cannot make paradise. Christianity posits that Jesus is savior of mankind, Islam recognizes Jesus as a prophet, while Mohammed remains the seal of the prophets. Granted then that both Christianity and Islam operate on the common orientation of monism, like theism and atheism, capitalism and scientific socialism, they remain doggedly opposed to each other. Both maintain their entrenched positions without any willingness to yield grounds. Is it then of any surprise that both Christianity and Islam are fanatical and intolerant of each other as well as other world religions.

Monotheism like metaphysical monism operates on the principle of dualism which is antithetical to African metaphysical pluralism which operates on the principle of duality. "Dualism, in philosophy, is the theory that the universe is explicable only as a whole composed of two distinct and mutually irreducible elements" (Microsoft Encarta, 2008). In dualism, opposites and contraries are seen to be in conflict or in antagonistic relationship. Dualism then operates on the law of dichotomy and by this law, contraries and opposites are polarized, making the affairs of the universe to rotate on a lope-sided linear scale. This explains why in Christianity and Islam there is a polarity between this world (earth) and the other world (heaven), between God and Satan, and between heaven and hell. For instance, in both Christianity and Islam, Satan is an eternal rival of God. Dualism as such operates strictly on the law of exclusivity. Duality on the other hand upholds that opposites and contraries are mutual, symbiotic and complementary. This explains why in the African thought process, the universe re- 
volves on a cyclical scale, so that centrifugally things move away from the centre, centripetally they return to the centre. There is then no divide between this world and that world, between heaven and hell. Besides, the African Satan is not a vain, wicked and callous entity who willfully wants to frustrate the work of God all the time. The Satan of ATR is rather an appointee of God who as a cosmic policeman oversees the affairs of the universe. And unlike the God of Christianity and Islam who is an absolute monarch, the God of ATR functions by way of delegation of duties (i.e. to the divinities). Evident in the foregoing is the fact that duality operates on the law of inclusivity.

By the law of inclusivity, reality is seen as being multi-faceted, multi-directional, multi-dimensional and pluralistic. By the law of exclusivity reality is seen as being unidirectional, uni-dimensional indivisible whole-hence, monistic. By the law of inclusivity entities are allowed to be the way they are (i.e. unaltered). By the law of exclusivity entities must be reduced to one supposedly superior and accepted mode of life. In this process, the original essences of these entities become bleached and altered. Now if the African mode of reasoning is that of inclusivity which promotes pluralism and if the mode of reasoning for Christianity and Islam is the law of exclusivity which promotes monism and reductionism, my question is: What rationale is behind the acceptance of metaphysical systems which are antithetically opposed as one common heritage? And if we now realize the foolhardiness in such a position, the question which also follows concerns how we can proceed about the amelioration of the anomaly on ground?

\section{Atonement of the African Condition}

As earlier stated, in traditional African thought system where spirit or force is regarded as the primordial operating principle and man is understood to be an embodiment of society and the cosmos, atonement is the process of propitiation and appeasement meant to reconcile man with other members of the society as well as the cosmic forces. The watchwords here are conciliation and reconciliation, which in actual fact are processes of integration. However, for the present exercise, I regard atonement to be an intellectual principle for construction and reconstruction meant to appraise the African condition with a view to rehabilitating such condition so that the African can overcome the confusion in which he finds himself entrapped. Atonement in this instance becomes a hermeneutic process for re-interpreting and deconstructing the African condition.

The beauty of hermeneutics is that it affords one the opportunity to interpret and deconstruct situations the way one deems it fit and in accordance with the facts on ground. In the first place, contrary to dialectics, hermeneutics posits that history is multi-directional, multi-dimensional and pluralistic. In an essay entitled: "Is the Wheel an Immutable Concept: A Dialectical/ Hermeneutical Delineation of Change”, I attempted a comparative analysis of dialectics and hermeneutics in relation to the problem of change. There I showed that contrary to the dialectical procedure which is linear, uni-directional and hence, monistic and reductionist; the hermeneutic procedure, being cyclical and multi-directional allows for a pluralistic assessment of issues and by so doing promotes pluralistic interpretation of human existence. Needless to say, such pluralistic outlook happens to be the prevailing orientation in the contemporary world order. It forms the core of African metaphysics, herme- neutic phenomenology and postmodernism. Therefore, my choice of hermeneutic deconstruction of the African condition through the process of atonement is not only adequate but timely.

Besides, hermeneutic deconstruction as atonement follows the procedure of double demolition. By this is meant the intellectualization and secularization of African spirituality, wherein is locked up the metaphysical principle of integration, which should in turn act as the foundation for deconstructing EuroChristian and Arab-Islamic traditions in order to purge them of the dogmas of monism and reductionism. Recall I stated that by the African condition, I understand a pluralistic society in which reside three world traditions which are diametrically opposed such that cohesion and progressive development are seriously hampered. It is only wise and proper that the resolution of such conflicting situation should be done by inculcating into the psyche of the people a pluralistic orientation. Once this pluralistic orientation firmly takes root in the collective psyche of Africans, it will help to re-enact the syncretic attitude of "live and let live" or the "win win" temperament which used to be the hallmark of African existence.

In the pre-colonial years when Arab and European cultures had not intruded upon Africa, pluralism informed the way of life for Africans. This very spirit which held Africans together was broken upon colonization. Chinua Achebe captures it succinctly in the following words: "Now he has won our brothers and our clan can no longer act like one. He has put a knife to the things that held us together and we have fallen apart" (1984: pp. 124-125). The "he" being talked about here is no other than the erstwhile colonizer who, using religion as a potent force, disemboweled African culture. In Petals of Blood Ngugi Wa Thiong'o precisely explains how the African spirit was disemboweled.

Today children, I am going to tell you about the history of Mr. Blackman in three sentences. In the beginning he had the land and the mind and the soul together. On the second day they took his body away to barter it for silver coins. On the third day seeing that he was still fighting, they brought priests and educators to bind his mind and soul so that these foreigners could easily take his land and produce (1977: p. 236).

The tools for systematic colonization of Africa were religion and education. In Things Fall Apart Achebe reiterates the foregoing point through the story of Mr. Brown the missionary at Umuofia who upon seeing that proselytization brought little progress decided on systematic conversion through education. Thus the principal goal of colonial education was to teach: The children to learn to obey what the missionary recommends, who is the father of their soul, to ensure their total submission and obedience (to the will of the colonizer), and to avoid developing the spirits in the schools-to teach students to read and not to reason (Hylton, 2003).

Colonialism had the agenda of abolishing African culture and its place, transplant and transpose the culture of the colonizer upon the African. It is such nihilistic act that created the problem of the Estranged African Psyche. Through the process of decolonization, African independence leaders were supposed to reintegrate the African back to his culture so that the African can find in his culture the esteem required for regaining his personality. A plethora of ideological orientations emerged to 
tackle the African condition. Among such ideological orientations are African Socialism, Democratic Socialism and NeoWelfarism. But the decolonization project of African independence leaders was fraught with one fundamental problem. African independence leaders also suffered from the problem of alienation. This was largely responsible for why most of them could not see the basic difference between the African metaphysical orientation and the metaphysical system of the colonizer. Granted some of them such as Julius Nyerere and Leopold Senghor vehemently argued for a return to and a re-sustenance of African value system, but the programmes outlined by these two leaders were not comprehensive and adequate enough to achieve the goal of re-orientation. This perhaps, explains why the structures and institutions of colonialism were left intact. For instance, religion and education, the very tools for re-orientation (i.e. decolonization) were left in the hands of missionaries who are principally agents of colonialism. So, give and take, decolonization met with failure because African independence leaders relied on ideological and religious systems whose metaphysical and epistemological orientations are diametrically opposed to the African traditional world outlook. Like I pointed out in another paper entitled: "Ontological Evaluation of Decolonization Theory in Postcolonial African Philosophy”, insofar as there was ideological alienation, it means that decolonization did not take place. If at all it did, then, what took place as decolonization lacked profundity, at best, it was mere window dressing.

Kwame Nkrumah is one leader who addressed the problem of the dissociated African conscience directly. Nkrumah quite understood the fact that colonialism left Africa in a most complex, confusing and devastating state and that there was the urgent need to reverse this state of anomaly. As he states:

Our society is not the old society, but a new society enlarged by Islamic and Euro-Christian influences. A new emergent ideology is therefore required, an ideology which can solidify in a philosophical statement but at the same time an ideology which will not abandon the original humanist principles of Africa (1978: p. 70).

Nkrumah proposed Philosophical Consciencism (Ibid.) as the "ideological orientation whose aim shall be to contain the African experience of Islamic and Euro-Christian presence as well as the experience of the traditional African society, and, by gestation, employ them for the harmonious growth and development of that society" (Ibid.). The proposed principle of harmonizing the conflict on the African soil and in the African conscience is known as Categorial Conversion. This principle takes dialectical materialism to be its operating methodology. But the materialist dialectics Nkrumah speaks of is one that acknowledges the duality of matter and mind. In which case, philosophical consciencism takes matter to be the "primary realty, not the sole reality" (Ibid. 88). Thus, he rejects the theory that matter is motionless (inert). He also rejects the theory that matter is apathetic to motion (inertia). For him, matter is dynamic. Matter is simply plenum of forces and its dynamism lays in the fact that every quantitative transformation results in a qualitative change, in the elevation of the human condition from a lower to a higher form of existence.

Perhaps, Nkrumah's emphasis on matter is hinged on the Marxian truism that the real source of exploitation is not religion but the control of capital by the ruling class, who use relig- ion as a smoke screen, and who in this instance is the imperialist or the erstwhile colonizer. The watchword therefore, was to gain control of state capital as a way of making sure that the new state builds wealth for the collective well being of the people. This might be the reason why Nkrumah advanced that the political kingdom should be sought after first and all other things shall follow. Nkrumah is quite right about this claim. Political autonomy is definitely the way to societal reconstruction, only that this bold proposal lost sight of two principal things.

First, in trying to invert Marxian materialism into African theory of forces and vice versa, Nkrumah was oblivious of the fact that he unwittingly merged two metaphysical systems which are diametrically opposed. The real problem here concerns how the monistic and reductionist metaphysical system of Marxian dialectical and historical materialism can be perfectly harmonized with the dualistic and pluralistic metaphysical system of traditional Africa? Such eclectic juxtaposition of diametrically opposed metaphysical systems would only generate further conflict in the society, in the same way as it would generate a conflicting account of man, mind, history etc. Needless to say, Nkrumah is not alone in this eclectic juxtaposition of metaphysical orientations which are diametrically opposed.

Second, Nkrumah's proposal lost sight of the proverbial saying charity begins at home. Bertrand Russell succinctly captures this fact thus: "In the advanced countries, practice inspires theory, in the others, theory inspires practice. This difference is one of the reasons why transplanted ideas are seldom so successful as they were in their native soil” (1972: p. 601).

Arab-Islamic and Euro-Christian intrusions dealt a devastating blow to African culture and imposed on Africans foreign modes of existence. A juxtaposition of these two alien traditions with the African one will only succeed in making Africans become second rate Europeans and second rate Arabs. The right and proper thing to do was to revamp the destroyed African foundation and use it to domesticate the two alien traditions. If we think this is improper, then we have no choice in the matter but to look to history to draw inspiration.

Africa is not the only one that has witnessed foreign domination nor is it the only one that has found itself is an utter state of confusion whereby there exists cultural conflict. Kamet (ancient Egypt) before and during the reign of Akhenaten had the problem of cultural conflict. Thus, Akhenaten's harmonization of the religious systems in ancient Egypt was principally aimed at building a common platform for political, economic and social cohesion. Again, in $325 \mathrm{AD}$, Constantine, through the Nicene Conference of 219 Bishops, formalized Christianity into the official religion of Roman Empire, all for the purpose of building a common political, economic and social hegemony. 570 AD marks the birth of Prophet Muhammad which also signals the ascendancy of the Arabs. Prophet Muhammad rallied his people around Islam so that they could have a platform to rebuff Christian and Jewish domination and subsequently make attempt at Islamizing the rest of the world. In the 16th century England, Henry VIII revolted against the Roman order. In place of the Holy Roman Catholic Church, he initiated the English or Anglican Church. He made English the official language of England, and also ordered that English history become the official history of the English. In 17th century Japan, the Tokugawa Dynasty, seeing that Christianity weakened the Japanese heritage, ousted the Christian missionaries, and ordered Japanese to return to the indigenous religion. To save Japan from further 
contamination, those who refused to revert to the traditional order were promptly executed. As recent as 1948, upon gaining control of China, Mao proceeded to clear China of the confusion into which it was entangled. He banned Christianity and Islam in China and made Confucianism the official way of life for the Chinese.

From the summation made above, it is clear that apart from Akhenaten whose action violated the serenity of ancient Egyptian society, from Constantine down to Mao, the intention was to reconstruct an already decadent situation. This apart, Akhenaten and Constantine's actions show that religion is central to socio-politico-economic organization. From Prophet Muhammad down to Mao, the point is made that religion must cohere with culture for there to be societal cohesion and balance. Going down historical memory therefore, we can see that those who obeyed the common injunction "charity begins at home" were able to substantially and comprehensively surmount the problem of alienation. The same cannot be said of Africa where African leaders have failed to continuously heed this injunction.

Consequently, upon the attainment of independence what the African leadership should have down was to develop a programme for re-integrating the African back into his culture. The aim of such programme would be to train and empower a crop of intelligentsias whose task it is to embark upon the intellectualization and secularization of the knowledge corpuses locked up in traditional African institutions. Such a project is meant to exhume the principle of pluralism locked up in African spirituality, which would then be made the basis of a National Orientation Education Programme for re-orienting the society. The purpose of such education system would be to make the African to touch base with the essence of his culture. At this level of mental exposure, the African comes to value and love his culture. And having understood the essence of his culture, he proceeds to make it the basis for evaluating and adapting foreign ideals. This way, Arab-Islamic and Euro-Christian traditions would become domesticated, infused with the pluralistic orientation and divested of their monistic, reductionist and absolutist toga. This way, the African syncretic spirit will be re-enacted such that the African would think of Islam and Christianity within the African context.

\section{Conclusion}

The attempt to make the African pluralistic orientation as the basis for ameliorating the African Personality problem caused by monistic and monotheistic orientations has been hinted at by Maduabuchi Dukor in his treatment of the triple heritage problem. He makes allusion to Olu Holloway, a grandmaster of the Freemanson and Olori Oluwo of Reformed Ogboni Fraternity (ROF), both of whom crave for how the pluralistic nature of ATR could be harnessed for the resolution of religious crisis in Black Africa.

In my view the African condition will keep getting worst if we do not toe the line of thought suggested by Maduabuchi Dukor. Wise civilizations do not depart from the metaphysical systems which form the hob of their cultures. In actual fact, a people's culture is defined by their spirituality and in their spirituality lays their metaphysical system which in turn embellishes the totality of their thought system, particularly, their religious and educational systems. In the first place, religion is metaphysics for the masses, while education has the task of secularizing a people's spirituality for the purpose of meeting up with contemporary challenges. These two must never be left in the hands of foreigners or in the hands of agencies and agents representing foreign interest. Besides, a wise government must use every dynamic process possible to ensure that religion is domesticated through a home grown educational programme. Religion and education are pivotal to national unity. Whichever government ignores this injunction is bound to lose both country and citizens to foreign control. Religion and education are great weapons for dissociating the psyche of the people and the unity of a nation (i.e. if both are alien to the culture of the people). But if domesticated, religion and education are also great weapons for instituting national unity and cohesion.

\section{REFERENCES}

Achebe, C. (1984). Things fall apart. Ibadan: Heinemann Educational Books.

Bohm, D. (1986). Creativity: The signature of nature. In R. Weber (Ed.), Dialogue with scientists and sages: The search for unity. New York: Routledge \& Kegan Paul Plc.

Chinweizu (2005). Gender and monotheism: The assault by monotheism on African gender diarchy. Anatomy of female power: A masculinist dissection of matriarchy (New ed.). Lagos: Pero Press.

Dukor, M. (2010). Theistic humanism of African philosophy: The great debate on substance and method of African philosophy. Berlin: LAP LAMBERT Academic Publishing GmbH \& Co. KG.

Edwards, D. L. (1988). Theism. In A. Bullock, O. Stallybrass, \& S. Trombley), The fontana dictionary of modern thought. Great Britain: Fontana Press.

Gardiner, A. (1964). Egypt of the pharaoh. London: Oxford University Press.

Heidegger, M. (1962). Being and time. Oxford: Basil Blackwell.

Hylton, Z. (2003). Africa the authentic land of Canaan. Lagos: Spectrum.

Idoniboye, D. E. (1973). The idea of African philosophy: The concept of spirit in African metaphysics. Second Order, 2, 83.

Idowu, B. (1982). Olódùmarè: God in Yoruba belief. Ibadan: Longman.

Iroegbu, P. (1995). Metaphysics: The Kpim of philosophy. Owerri: International University Press.

Kant, I. (1970). Critique of pure reason. London: Macmillan.

Lewis, H. D. (2010). Theism. In Encyclopaedia britannica student and home edition. Chicago: Encyclopædia Britannica.

Matt, D. C. (1997). The essential Kabbalah: The Heart of Jewish Mysticism. New Jersey: Castle Books.

Microsoft Encarta (2008). Microsoft Corporation.

Nkrumah, K. (1978). Consciencism: Philosophy and ideology for decolonization. London: Panaf Books Ltd.

Omoregbe, J. I. (1983). What is god? A critical enquiry. The Nigerian Journal of Philosophy, 3, 1-24.

Osahon, N. (2002). The end knowledge. Lagos: Heritage Books.

Podolny, R. (1986). Something called nothing, physical vacuum: What is it? Moscow: Mir Publishers.

Russell, B. (1972). A history of western philosophy. New York: A Touchstone Book.

Smart, N. (2010). Polytheism. In Encyclopaedia britannica student and home edition. Chicago: Encyclopædia Britannica.

Unah, J. I. (1995). Essays in philosophy. Lagos: Panaf Books Incorporation.

Unah, J. I. (1997). Heidegger, through Kant to fundamental ontology. Ibadan: Hope Publications.

Unamuno, M. D. (1954). Tragic sense of life. New York: Dover Publications Inc.

Wa Thiong'o N. (1977). Petals of blood (African writers series). Nairobi: Heinemann.

Watson, J. (1971). Heidegger's hermeneutic phenomenology. In Philosophy Today, 15.

Weber, R. (1986). Dialogue with scientists and sages: The search for unity. New York: Routledge \& Kegan Paul Plc. 